УДК 7.01

doi: 10.32620/gch.2019.4.15

Северин В. Д., Северин Н. В.

\title{
ДЖЕРЕЛО СТВОРЕННЯ АСОЩІАТИВНОГО ОБРАЗУ В ДИЗАЙНІ
}

У статті розглянуто роль дизайну у створенні нового інформаційного простору. Визначено роль студентської олімпіади в сучасних умовах підготовки молодих фахівців із дизайну. 3'ясовано мету проведення олімпіади: підвищення якості підготовки кваліфікованих фахівців, пошук обдарованої студентської молоді, стимулювання ї̈ творчої діяльності. Підкреслено значення студентської олімпіади з дизайну.

Ключові слова: дизайн, студентська олімпіада з дизайну, проектно-графічне моделювання, асоиіативно-образна композиція, площинна композиція.

The article deals with the role of design in creating a new information space. The role of the student Olympiad in modern conditions of training young specialists in the field of design is determined. The goal of the Olympiad, which is to improve the quality of training of qualified specialists, the search for gifted students, stimulating their creative activity is determined. The importance of the student Olympiad is underlined.

Keywords: design, student design Olympiad, design graphic modeling, associative composition, planar composition.

Постановка проблеми. В умовах сьогодення в Україні спостерігається процес створення нового інформаційного простору, у реалізації якого помітну роль відіграє дизайн. Теорія дизайну подана великою різноманітністю концепцій і думок щодо його цілей, методів і засобів. Судження про дизайн залежать від комплексу соціальноекономічних i культурно-естетичних чинників суспільних систем. Дослідники зазначають, що дизайн виник на перетині науки, техніки й мистецтва, він реалізується в різних соціальних системах i підпорядкований соціальним i природним закономірностям.

Аналіз наукових досліджень свідчить, що основними працями, присвяченими вивченню проблем дизайну, можна назвати дослідження Р.Р. Клікса, В.В. Литвинова, В.Р. Аронова, але вони були видані в 70-80-х рр. ХХ ст. Монографія Р.Р. Клікса «Художественное проектирование экспозиций» (1978 р.) [7] $\epsilon$ першим систематизованим узагальненням досвіду художнього проектування експозиційних просторів на пострадянському просторі та за кордоном. Вона присвячена висвітленню питань просторового розв'язання інтер'єру, виставкової архітектури, виставкового дизайну. В.М. Шпаков у книзі «История всемирных выставок» [10] подає історичну ретроспективу й повну характеристику всесвітніх виставок. В.Р. Аронов у праці «Художник и предметное творчество. Проблемы взаимодействия материальной и художественной культуры XX века» [1] уводить до власне мистецтва поняття «предметна творчість», яке надає можливість подати матеріальне оточення людей як основу художньої культури будь-якої епохи й будь-якого регіону. Л.Н. Безмоздін у 
монографії «В мире дизайна» [2] виклав природу дизайну в зіставленні з технічною й художньою підсистемами культури й розкрив методологічні засади вдосконалення теорії та практики дизайну. Вагомим дослідженням трьох американських дизайнерівпрактиків Я. Лоренца, Л. Сколніка, К. Бергера $є$ «Дизайн выставок: практическое руководство» [9], присвячене історії, актуальним проблемам і процесу сучасного виставкового дизайну. В Україні особливої уваги набули дослідження основ дизайну, дизайну в Україні, дизайну Центрально-Східної Свропи в працях доктора мистецтвознавства, професора В.Я. Даниленка [5; 6]. Сучасні мистецтвознавчі студії висвітлюють окремі грані дизайну в Україні в ХХ ст. У роботах Б. Бондаренка [3], Н. Брижаченко [4], Л. Коваль [8] досліджено проблеми формування предметнопросторового середовища засобами інтерактивних технологій. На нашу думку, в умовах сьогодення варто наголосити, що дизайн - це творча діяльність, яка завжди має місце в системі людської діяльності та є вагомим явищем культури, виконуючи різні культурні функції. У зв'язку з цим слід приділити увагу художньо-виразним засобам та формуванню художнього образу в дизайні, що стане метою цієї статті.

Виклад основного матеріалу. Сучасними принципами дизайну є поєднання в цілісній структурі й гармонійній формі всіх суспільно необхідних властивостей проєктованого об'єкта. Основними робочими категоріями дизайнерського проектування є образ, функція, морфологія, технологічна форма, естетична цінність. Реалізація ідеї створення цілісного об'єкту вимагає глибокого знання основних законів і тенденцій розвитку економіки, виробництва, споживання, а також розуміння духовних запитів суспільства. Тому дизайн грунтується на наукових засадах моделювання об'єкта, об'єднуючи наукові принципи 3 художніми в проектному образі, і знаходить застосування в інших галузях суспільної діяльності (соціальний дизайн).

Пошук нових дизайнерських розв'язків зумовлений культурною трансформацією в сприйнятті глядачів. Тому формування нових прийомів орієнтоване на досягнення гармонії між предметом i його оточенням, на легкість сприйняття інформації відвідувачем, що забезпечуються мультимедійними технологіями, які розширюють інформаційну складову експозиції, дозволяють представити предмет у контексті віртуального простору, стають засобом створення інтерактивних взаємодій і розваг.

Протягом усього періоду розвитку дизайну відбувалась еволюція не тільки художньо-виразних засобів, але й художнього образу. До акцентування уваги на образній складовій дизайн залишався ніби за межами мистецтва й дизайну. Він виконував організаційну функцію - оформлення, подання, розташування предмета колекції в експозиції, створення сприятливого, а потім і оптимального середовища для його сприйняття, тобто вирішувалися питання утилітарної, архітектурної та предметної організації середовища в межах панівного художнього стилю. Однак із розробленням візуального образу в системі художньої інтерпретації й контексту статус експозиційної побудови докорінно змінюється. 3 декорувального, ілюстративного й функціонально-утилітарного він стає художньо-виразним.

В умовах сьогодення вкрай важливо вміти орієнтуватися на запити суспільства й навчати молодих фахівців із дизайну творчо мислити, активно сприяти розвитку в них 
професійно орієнтованих здібностей, які б відповідали не тільки українським, але й міжнародним стандартам. Із цією метою в українських мистецьких закладах вищої освіти щороку проводяться студентські олімпіади.

Проведення Всеукраїнської студентської олімпіади з дизайну в закладах вищої освіти України вже стало постійним, важливим, запитуваним часом явищем. Олімпіада проводиться згідно з Положенням, затвердженим наказом Міністерства освіти і науки, молоді та спорту України (№ 1410 від 13 грудня 2012 року) 3 метою підвищення якості підготовки кваліфікованих фахівців і методів їхньої підготовки, пошуку обдарованої студентської молоді, стимулювання її творчої праці. Такий захід сприяє виявленню в студентів професійно орієнтованих здібностей, налагодженню творчих зв'язків і дружніх відносин між дизайнерськими освітніми закладами України, дає змогу виявити переможців серед найталановитіших учасників і таким чином провести відбір студентів для участі в міжнародних олімпіадах з дизайну. Тож починаючи з 2012 р. Всеукраїнська студентська олімпіада 3 дизайну проводиться й на базі Харківської державної академії дизайну та мистецтв (яка стала базовим закладом), набираючи все більшого розмаху: розширюється географія навчальних закладів, що беруть участь у олімпіаді, зростає кількість учасників, поліпшується якість їх творчих розробок. Зосередимо увагу на проведенні олімпіади в останні 2018 та 2019 рр. Темою олімпіади 3 дизайну 2018 р. було визначено «Архітектурний мотив як основа площинної та просторової інтерпретації форми», у зв’язку з якою на меті стало виявлення та оцінка знань, умінь, навичок студентів у створенні й представленні концепт-ідеї та іiі реалізація в проектних пропозиціях. Контингент учасників склали студенти навчальних закладів освіти III та IV рівнів акредитації за спеціалізаціями «Промисловий дизайн», «Графічний дизайн», «Дизайн середовища», «Дизайн архітектурного середовища», «Дизайн текстилю та одягу», «Дизайн меблів», «Декоративно-ужиткове мистецтво». Методологічною основою завдань став проектний експеримент, у процесі якого учасники мали в короткий час реалізувати ідейний задум із використанням засобів проектно-графічного моделювання.

Програма олімпіади передбачала два етапи проведення й визначала зміст кожного етапу. Завданням першого етапу було створення фронтальної асоціативної композиції на задану тему шляхом інтерпретації запропонованого архітектурного твору, його форми, просторової організації, концепції. Завдання мало виконуватися в техніці графіки 3 елементами рельєфу та 3 використанням не більше двох хроматичних кольорів. Змістом другого етапу було створення об'ємно-просторової тематичної асоціативно-образної композиції шляхом подальшого розвитку площинної композиції. Новизною в проведенні олімпіади було конкурсне завдання з виконання композиції на задану тему шляхом інтерпретації певного архітектурного твору, яка розкривала як графічне, так і об'ємно-просторове рішення композиції.

За́даним об’єктом за темою був Держпром, або Будинок Державної промисловості, - перший в Україні 13-поверховий хмарочос, пам'ятка архітектури в стилі конструктивізму, одна 3 трьох харківських «висоток», збудована впродовж 1926-1928 рр. Споруда розташовується на центральній площі міста Харкова майдані Свободи. Для надання студентам інформаційної допомоги в ознайомленні 3 
об’єктом ми нагадуємо історичні дані: про оголошення конкурсу 5 травня 1925 р. на кращий проект будівлі (всього було подано 19 проектів); про переможців конкурсу групу ленінградських архітекторів Сергія Серафімова, Самуїла Кравця, Марка Фельгера; про урочисте відкриття Держпрому, збудованого в стилі конструктивізму, 7 листопада 1928 р.; про стиль «конструктивізм», який характеризується суворістю, геометризмом, лаконічністю форм, монолітністю зовнішнього вигляду тощо.

Критерії оцінювання робіт охоплювали: відповідність виконаної роботи темі завдання; відповідність вибору графічних засобів оптимальному розкриттю художнього задуму композиції; оригінальність художньо-образного розв'язку; виразність розвитку ідей графічної композиції в її об'ємно-просторовій інтерпретації; професійний рівень виконання завдання: навички створення гармонійної композиції в заданому форматі, якість графічного подання й макетування, грамотність у формулюванні концепції. Оцінювало роботи студентів компетентне професійне журі 3 дев'яти осіб - представників закладів освіти з різних міст України. Кожне завдання оцінювалося за десятибальною шкалою. Переможцями Всеукраїнської студентської олімпіади 3 дизайну 2018 р. стали студенти Харківської державної академії дизайну і мистецтв, Придніпровської державної академії будівництва та архітектури, Запорізького національного технічного університету, Хмельницького національного університету та Харківського національного університету будівництва та архітектури. У цій олімпіаді взяли участь 35 студентів із 16 закладів вищої освіти України.

16-18 квітня 2019 р. на базі Харківської державної академії відбувся II тур Всеукраїнської студентської олімпіади зі спеціальності «Дизайн». Учасниками стали переможці першого туру, який проводився на базі своїх закладів освіти. Темою олімпіади було визначено «Музичний твір як джерело формування асоціативного образу в дизайні». Метою цього заходу стало виявлення й оцінка знань, умінь і рівня проектно-образного мислення й творчої індивідуальності студентів. Завдання було орієнтоване на формування якісно нових творчих рішень, активізацію й винахідливість студентів-дизайнерів різних спеціалізацій, збагачення їхньої проектної культури, розширення світогляду з метою генерування оригінальних і перспективних новаторських дизайн-концепцій. Новизною в проведенні олімпіади було конкурсне завдання щодо виконання композиції на задану тему шляхом формування асоціативного образу під час прослуховування певного музичного твору, яка мала розкрити як графічний, так і об'ємно-просторовий розв'язок творчої роботи. Також новацією було ускладнення техніки виконання другого завдання: виконати не виключно графічну композицію, а графічну композицію з елементами оригінальних і перспективних новаторських дизайн-концепцій. Завдання мало на меті виявити ступінь та оцінку знань, умінь і рівня проектно-образного мислення й творчої індивідуальності.

За́даним музичним твором було обрано твір «Чотири пори року» - цикл із чотирьох скрипкових концертів італійського композитора Антоніо Вівальді, написаний у 1723 р. і опублікований у 1725 р. Кожен концерт присвячений одній із пір року і складається з трьох частин, що відповідають кожному місяцеві. Учасникам студентської олімпіади було запропоновано прослухати концерт № 2 «Літня гроза». 
Цей цикл став одним 3 найпопулярніших творів Вівальді, а також одним 3 найвідоміших музичних творів епохи бароко.

Методологічною основою завдань став проектний експеримент, у процесі якого учасники за короткий проміжок часу мали реалізувати ідейний задум із використанням засобів проектно-графічного моделювання. Першим завданням було виконання на базі музичного твору, згідно з заданою темою, абстрактної графічної композиції й надання анотації до графічної частини. У iї розв'язанні мав знайти відображення характер композиції музичного твору й бути встановлений асоціативний зв'язок із темою завдання.

На другому етапі учасники олімпіади на основі графічного розв'язку мали виконати об'ємно-просторову композицію на задану тему, яка мала передавати композиційну структуру музичного твору й відповідати темі завдання. Композиція мала грунтуватися на загальних принципах об’ємно-просторової структури й подавати тримірну інтерпретацію площинної структури. Завдання виконувалося на модулі А3 із наданням письмового обгрунтування проектної концепції об'єкту.

Критерії оцінювання робіт ураховували: відповідність виконаної роботи темі завдання; оригінальність художньо-образного розв'язку; виразність передання розвитку структури в об'ємно-просторовій композиції; професійний рівень виконання завдання; уміння компонувати складові завдання на форматі, якість графічного подання, якість макетування, грамотність у написанні концепціі; ступінь виявлення в художньо-образному рішенні асоціативного зв'язку з характером наданого музичного твору тощо. Журі олімпіади підсумовувало бали учасників за сумою двох завдань, кожне з яких оцінювалося за десятибальною шкалою.

Висновки. Дизайн $\epsilon$ оригінальною творчою діяльністю. Виявлення місця дизайну в системі людської діяльності дозволяє зрозуміти його як явище культури й осягнути його культурні функції. Важливим напрямком розвитку українського дизайну на найближчий час стане створення національно орієнтованого дизайну, що дасть змогу гідно представляти імідж України на міжнародній арені.

Щорічне проведення Всеукраїнської студентської олімпіади з дизайну в закладах вищої освіти України стало актуальним, запитуваним часом явищем. Олімпіада 3 дизайну стала яскравим підтвердженням, що всі види мистецтва існують у тісному взаємозв'язку i зазнають взаємовпливів. Незримий зв'язок кожної людини 3 навколишнім світом, із прекрасним, що в ньому існує, надихає кожного, а творчу людину й поготів, на створення яскравих, неперевершених творчих розв'язків i образів як у музиці, літературі, поезії, мистецтві, так і в дизайні. В умовах сьогодення це вкрай важливо, оскільки творчі надбання людства $\epsilon$ вічними скарбами, які зберігаються, примножуються й передаються від покоління до покоління. А завдання викладачів мистецького закладу вищої освіти - допомогти сучасній молоді побачити прекрасне й спрямувати їі діяльність на створення величних і вічних образів. 
Література:

1. Аронов В. Р. Художник и предметное творчество. Проблемы взаимодействия материальной и художественной культуры ХХ века. М. : Советский художник, 1987. 232 с.

2. Безмоздин Л. Н. В мире дизайна. Ташкент : ФАН, 1990. 316 с.

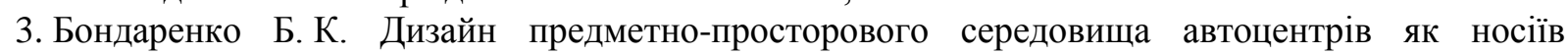
ідентичності корпоративних брендів : автореф. дис. канд. мистецтвознавства, спец. 17.00.07. Харків, 2015. $20 \mathrm{c}$.

4. Брижаченко Н. С. Композиційні прийоми організації інтер'єрів музейно-експозиційних комплексів, створених засобами інтерактивних технологій. Матер. Всеукр.наук. конф. : зб. $\mathrm{cm}$. ХДАДМ. Харків, 2014. С. 12-14.

5. Даниленко В. Дизайн України у світовому контексті художньо-проектної культури : монографія. Харків : ХДАДМ; Колорит, 2005. 224 с.

6. Даниленко В. Дизайн Центрально-Східної Європи : монографія. Харків : ХДАДМ, 2009. $172 \mathrm{c}$.

7. Кликс Р. Р. Художественное проектирование экспозиций : монография. М. : Высшая школа, 1978. $368 \mathrm{c}$.

8. Коваль Л. М. Принципи формування дизайну предметно-просторового середовища засобами LED - технологій : автореф. дис. канд. мист., спец. 17.00.07. Харків, 2012. 20 с.

9. Лоренц Я., Сколник Л., Бергер К. Дизайн выставок: практическое руководство / пер. с англ. П. В. Кодолова. М. : АСТ: Астрель, 2008. 256 с.

10. Шпаков В. Н. История всемирных выставок. М. : АСТ: Зебра Е, 2008. 384 с.

\section{References:}

1. Aronov, V. R. (1987), Artist and subject creation. Problems of interaction of material and artistic culture of the XX century, Soviet artist, Moscow.

2. Bezmozdin, L. N. (1990). In the world of design, FAN, Tashkent.

3. Bondarenko, B. K. (2015), Design of the subject-spacious medium of auto centers as a nose for corporate identity brands. Abstract dis. Cand. of Arthistory, speciality 17.00.07.

4. Brizhachenko, N. S. (2014), Compositions, Organizing Organizations, Museum and Exposition Complexes, Complicated with Interactive Technologies. Ukrainian sciences. conf., pp. 12-14.

5. Danilenko, V. (2005), Design of Ukraine in the context of art and design culture, KhDADM; Colorit, Kharkiv.

6. Danilenko, V. (2009), Design of Central Scheduled Europe, KhDADM, Kharkiv.

7. Klix, R. R. (1978), Artistic design of expositions, Higher School, Moscow.

8. Koval, L. M. (2012), The principles of formulating the design of a subject-spacious medium with LED - technology. Abstract dis. Cand.of Arthistory, speciality17.00.07.

9. Lorenz, J. (2008), Exhibition Design : A Practical Guide, AST, Astrel, Moscow.

10. Shpakov, V. N. (2008), History of World Exhibitions, AST : Zebra E, Moscow.

\section{Viktor Severyn, Nadiia Severyn}

\section{SOURCE OF ASSOCIATIVE IMAGE CREATION IN DESIGN}

Under today's conditions in Ukraine a process of a new information-driven society creation is observed, where design plays a prominent role. Design appeared at the intersection of science, technology and art; it is implemented in different social systems and conforms to social and natural laws. Under today's circumstances design is creativeness, 
which always has its place in people's activity and is defined as an important cultural phenomenon, performing different cultural functions. The aim of the article is the definition of artistic-expressive means role in the artistic image creation in design, determination of Design Olympiad role for creative thinking cultivation and occupational skills in future specialists.

The holding of the All-Ukrainian Student Olympiad on Design in Ukrainian higher educational establishments has already become a constant, important, time-consuming event. Such an event contributes to revealing of students' professional abilities, establishing creative and friendly relations among art educational establishments of Ukraine, enables to decide the winners among the most talented participants and, thus it helps to select students for participation in International Olympiads on Design. Since 2012 on the basis of Kharkiv State Academy of Design and Fine Arts, which became the main establishment, the AllUkrainian Olympiad on Design has been held, gaining popularity and significance: more and more educational establishments are involved, the number of participants is growing together with the quality of their creative efforts. The Olympiad programme consists of two stages and determines each of them. In 2019 the purpose of this event was the knowledge evaluation, skills and students' design thinking level as well as their creative manner. The task was aimed at new creative solutions, activation and imagination in student designers of different specialties, enrichment of design culture, outlook broadening with the objective of original and perspective innovative design conceptions generation. Whereas art higher educational establishment teachers' task is to help the modern youth see beauty and direct their activity to create magnificent and eternal images.

Keywords: design, student design Olympiad, design graphic modeling, associative composition, planar composition.

\section{Віктор Северин, Надія Северин}

\section{ДЖЕРЕЛО СТВОРЕННЯ АСОЦІАТИВНОГО ОБРАЗУ В ДИЗАЙНІ}

В умовах сьогодення в Україні спостерігається процес створення нового інформаційного простору, у реалізації якого помітну роль відіграє дизайн. Дизайн виник на перетині науки, техніки й мистецтва, він реалізується в різних соціальних системах і підпорядкований соціальним і природним закономірностям. В умовах сьогодення дизайн - це творча діяльність, яка завжди має місце в системі людської діяльності та $є$ вагомим явищем культури, виконуючи різні культурні функції. Мета статті - визначення ролі художньо-виразних засобів у формуванні художнього образу в дизайні, з'ясування значення проведення олімпіад 3 дизайну для виховання в майбутніх фахівців творчого мислення та професійно орієнтованих здібностей.

Проведення Всеукраїнської студентської олімпіади 3 дизайну в закладах вищої освіти України вже стало постійним, важливим, запитуваним часом явищем. Такий захід сприяє виявленню в студентів професійно орієнтованих здібностей, налагодженню творчих зв'язків і дружніх відносин між дизайнерськими освітніми закладами України, дає змогу виявити переможців серед найталановитіших учасників 
i таким чином провести відбір студентів для участі в міжнародних олімпіадах 3 дизайну. Починаючи з 2012 р. на базі Харківської державної академії дизайну та мистецтв (яка стала базовим закладом) проводиться Всеукраїнська студентська олімпіада 3 дизайну, набираючи все більшого розмаху: розширюється географія навчальних закладів, що беруть участь в олімпіаді, зростає кількість учасників, поліпшується якість їхніх творчих розроблень. Програма олімпіади передбачає два етапи проведення й визначає зміст кожного етапу. Метою цього заходу в 2019 р. стало виявлення та оцінка знань, умінь і рівня проектно-образного мислення й творчої індивідуальності студентів. Завдання було орієнтоване на формування якісно нових творчих розв'язків, активізацію і винахідливість студентів-дизайнерів різних спеціалізацій, збагачення їх проектної культури, розширення світогляду з метою генерування оригінальних і перспективних новаторських дизайн-концепцій. Завдання викладачів мистецького закладу вищої освіти - допомогти сучасній молоді побачити прекрасне й спрямувати ії діяльність на створення величних і вічних образів.

Ключові слова: дизайн, студентська олімпіада з дизайну, проектно-графічне моделювання, асоціативно-образна композиція, площчинна композиція.

Severyn Viktor - Ph.D. in Art history, Associate Professor, Department Environmental Design Kharkiv State Academy of Design and Arts (Kharkiv).

Северин Віктор - кандидат мистецтвознавства, доцент кафедри «Дизайн середовища», Харківська державна академія дизайну і мистецтв (м. Харків).

e-mail: severiny84@gmail.com

Северин Надія - кандидат філософських наук, доцент, завідувач кафедри гуманітарних наук факультету міжнародної освіти, Національний технічний університет «Харківський політехнічний інститут».

Severyn Nadiia - Ph.D. in Philosophy, Associate Professor, Head of the Chair of Humanities National Technical University «Kharkov Polytechnic Institute».

e-mail: severiny84@gmail.com

Надійшла до редакції 30.10.2019. Розглянута на редколегії 19.11.2019.

\section{Рецензенти:}

Доктор філософських наук, професор, професор кафедри суспільно-гуманітарних дисциплін Харківського Національного університету будівництва та архітектури Проценко О. П.

Кандидат філософських наук, доцент, доцент кафедри права гуманітарного факультету Національного аерокосмічного університету ім. М. С. Жуковського «Харківський авіаційний інститут» Васильєва Л. А. 